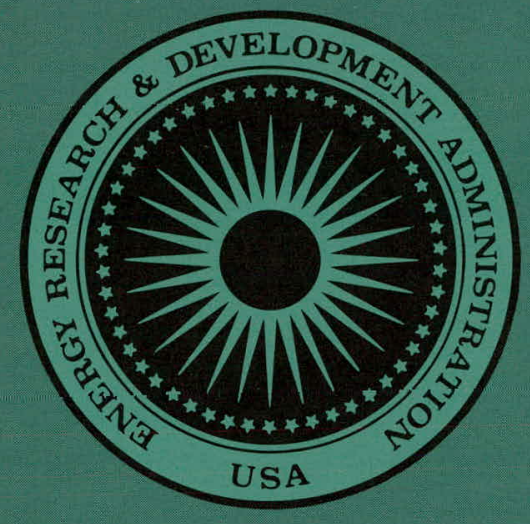

BERC/RI-77/2

CHEMICAL EXPLOSIVES FRACTURING FIELD DEMONSTRATIONS FINAL REPORT

By

Petroleum Technology Corporation

Under ERDA Contract No. E(34-1)-0001

Date Published January 1977

Bartlesville Energy Research Center

Energy Research and Development Administration

Dartlesville, Oklahoma 


\section{DISCLAIMER}

This report was prepared as an account of work sponsored by an agency of the United States Government. Neither the United States Government nor any agency Thereof, nor any of their employees, makes any warranty, express or implied, or assumes any legal liability or responsibility for the accuracy, completeness, or usefulness of any information, apparatus, product, or process disclosed, or represents that its use would not infringe privately owned rights. Reference herein to any specific commercial product, process, or service by trade name, trademark, manufacturer, or otherwise does not necessarily constitute or imply its endorsement, recommendation, or favoring by the United States Government or any agency thereof. The views and opinions of authors expressed herein do not necessarily state or reflect those of the United States Government or any agency thereof. 


\section{DISCLAIMER}

Portions of this document may be illegible in electronic image products. Images are produced from the best available original document. 


\section{NOTICE}

This report was prepared as an account of work sponsored by the United States Government. Neither the United States nor the United States Energy Research and Development Administration, nor any of their employees, nor any of their contractors, subcontractors, or their employees, makes any warranty, express or implied, or assumes any legal liability or responsibility for the accuracy, completeness or usefulness of any information, apparatus, product or process disclosed, or represents that its use would not infringe privately owned rights.

This report has been reproduced directly from the best available copy.

Available from the National Technical Information Service, U.S. Department of Commerce, Springfield, Virginia 22161.

\begin{tabular}{|c|c|c|c|c|c|c|c|c|c|c|c|}
\hline $\begin{array}{l}\text { Page } \\
\text { range }\end{array}$ & $\begin{array}{l}\text { Domestic } \\
\text { price }\end{array}$ & $\begin{array}{l}\text { Page } \\
\text { range }\end{array}$ & $\begin{array}{l}\text { Domestic } \\
\text { price }\end{array}$ & $\begin{array}{l}\text { Page } \\
\text { range }\end{array}$ & $\begin{array}{c}\text { Dumestic } \\
\text { price }\end{array}$ & $\begin{array}{l}\text { Page } \\
\text { range }\end{array}$ & $\begin{array}{c}\text { Domestic } \\
\text { price }\end{array}$ & $\begin{array}{l}\text { Page } \\
\text { range }\end{array}$ & $\begin{array}{c}\text { Domestic } \\
\text { price }\end{array}$ & $\begin{array}{l}\text { Paqe } \\
\text { range }\end{array}$ & $\begin{array}{c}\text { Domestic } \\
\text { price }\end{array}$ \\
\hline 01.025 & $\$ 3.50$ & $126-150$ & $\$ 6.00$ & $251-275$ & $\$ 9.00$ & $376-400$ & $\$ 10.75$ & 501.525 & $\$ 12.75$ & $701-800$ & $\$ 18.75$ \\
\hline 026.050 & $\$ 4.00$ & $151-175$ & $\$ 6.75$ & $276-300$ & $\$ 9.25$ & $401-425$ & $\$ 11.00$ & 526.550 & $\$ 13.00$ & $801 \cdot 900$ & $\$ 21.25$ \\
\hline 051.075 & $\$ 4.50$ & $176-200$ & $\$ 7.50$ & $301 \cdot 325$ & $\$ 9.75$ & $426-450$ & $\$ 11.75$ & $551-575$ & $\$ 13.50$ & $901-1000$ & $\$ 23.75$ \\
\hline $076-100$ & $\$ 5.00$ & $201-225$ & $\$ 7.75$ & 326350 & $\$ 10.00$ & $451-475$ & $\$ 12.00$ & 576.600 & $\$ 13.75$ & $1001-1100$ & $\$ 28.25$ \\
\hline $101-125$ & $\$ 5.50$ & $226-250$ & $\$ 8.00$ & 351.375 & $\$ 10.50$ & $476-500$ & $\$ 12.50$ & $601-700$ & $\$ 16.25$ & $1101-1200$ & $\$ 32.75$ \\
\hline
\end{tabular}

For additional pages, add $\$ 4.50$ for each beginning 100 pages. Add $\$ 2.50$ per copy for foreign price.

Microfiche $\$ 3.00$ (domestic) $\$ 4.50$ (foreign). 
BERC/RI-77/2

Distribution Category UC 92a

\title{
CHEMICAL EXPLOSIVES FRACTURING FIELD DEMONSTRATIONS FINAL REPORT
}

\author{
By \\ Petroleum Technology Corporation \\ Post Office Box 537 \\ Redmond, Washington 98052 \\ Prepared for ERDA \\ Under Contract No. E(-4-1)-0001
}

Date Written-May 27, 1976

Date Published-January 1977

Subriltted to

Dartlosvillo Energy Research Conter

Bartlesville, Oklahoma

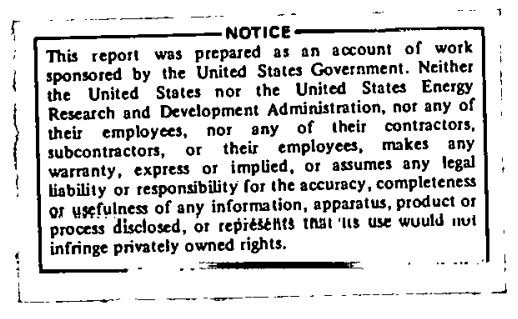

UNITED STATES ENERGY RESEARCH AND DEVELOPMENT ADMINISTRATION TECHNICAL INFORMATION CENTER 


\section{TABLE OF CONTENTS}

$\begin{array}{ll}\text { I. } & \text { CONCLUSIONS } \\ \text { II. } & \text { RECOMMENDATIONS } \\ \text { III. } & \text { INTRODUCTION AND SUMMARY } \\ \text { IV. } & \text { HISTORY OF TEST WELLS } \\ \text { V. } & \text { PREPARATION OF EQUIPMENT AND WELLS } \\ \text { VI. } & \text { FIELD DEMONSTRATIONS } \\ \text { VII. } & \text { EVANALUATION OF RESULTS }\end{array}$




\section{CONCLUSIONS}

1. It has been demonstrated in three separate field demonstrations that the PTC system can be employed to safely manufacture and inject large quantities of liquid explosive into natural or hydraulically induced fractures in typical hydrocarbon bearing formations.

2. The producing capability of the first test well, Hampshire No. 10, was not enhanced by chemical explosive fracturing stimulation.

3. Analysis of pressure buildup tests results conducted before and after the second field demonstration indicate that Hampshire No. 18's flow potential was increased by a factor of 1.66 by the chemical explosive fracturing stimulation test. A commercial well was not, however, obtained.

4. Even though most of the open hole section of the third test well, Columbia No. 20117-T, could not be cleaned out, the gas production rate was increased threefold and the formation's capacity to produce ("kh" factor) was increased tenfold. Again, however, a commercial well was not obtained.

5. An inadequate pressure relieving device resulted in damage to PTC's automatic wellhead assembly when detonation occurred in the second field demonstration. Additional and larger pressure relief devices have been added to the assembly in an effort to eliminate the future possibility of this occurrence.

6. Motorola has withdrawn from all development work on a detonation system and PTC is currently in the process of developing and testing a command fire detonation system. 
7. A water leak that resulted from a poor cement job prevented complete cleanout of Columbia No. 20117-T and, therefore, eliminated the possibility of evaluating the effects of rubble on gas flow rate. 


\section{RECOMMENDATIONS}

In order to fully evaluate the potential of the chemical explosive fracturing concept, it is recommended that additional test programs utilizing various types of formations in different geographic locations, be undertaken. The test wells chosen should offer reasonable potential for obtaining meaningful test results.

The primary objective of additional test programs should be to determine the cost effective ness of this concept. They should, however, be designed to meet other objectives such as determining the effects of rubble on production. 


\section{INTRODUCTION AND SUMMARY}

In June, 1974, the United States Bureau of Mines and Petroleum Technology Corporation entered into an agreement for testing PTC's high pressure chemical explosive fracturing system in three noncommercial Oriskany sand wells owned by Hampshire Gas Company. The contract was subsequently transferred to the U.S. Energy Research and Development Administration and modified so that the third well tested was a Devonian shale well owned by Columbia Gas Systems.

Prior to conducting the field demonstrations, a detailed safety and hazards analysis of PTC's system and the planned test program was made by Hercules Incorporated at their Allegany Ballistics Laboratory. The results of this study indicated that the risks involved with the PTC system are considerably less than that associated with driving to work or working in a factory or plant.

The three field demonstrations have been completed and all required post test evaluations performed. With the exception of damaging PTC's wellhead assembly when detonation occurred in the second test, the field demonstrations were conducted without an incidence occurring. Only minor problems were encountered in performing the actual field demonstrations and procedural and equipment changes have been made to hopefully alleviate the possibility of their reoccurrence.

Evaluation of the test results shows that PTC's system can be used to safely manufacture and inject a liquid chemical explosive into natural gas bearing formations. Although numerous stimulation treatments had been performed on the first two test wells, the detonation in Hampshire No. 18 did increase the inflow characteristics of the well by a factor of 1.66 . No improvement was seen in Hampshire No. 10. Marked improvement was seen in the producing characteristics of the third test well, Columbia No. 20117-T, even though only 19 percent of the original open hole section could be cleaned out. The gas production rate was increased threefold to 43 MCF and the formation's capacity to produce ("kh" factor) was increased tenfold. 
None of the tests resulted in a commercial gas well. However, only the last test well presented a real opportunity to obtain commercial production. Since a water leak caused by a poor cement job precluded complete cleanout of this well, the results of this test should not be considered conclusive. Further testing of the process is therefore warranted to determine its commercial viability and the effect of the wellbore rubble on gas production. 


\section{HAZARDS ANALYSIS \& COMPATIBILITY TESTS}

Prior to conducting the field demonstrations, a detailed hazards analysis of the PTC process and equipment was required by the contract. Hercules Incorporated performed this task at the Allegany Ballistics Laboratory (ABL) facility. The analysis concentrated on the hazards of operating PTC high pressure explosive fracturing system in general, and as it was to be utilized in performing the three field demonstrations.

This investigation concluded that a field test utilizing PTC's downhole mixing concept could be performed with $1.1 \times 10^{-7}$ probability of an incident occurring. In other words, the risk associated with PTC's system is considerably less than that associated with driving to work or working in a factory or plant. A copy of the final report received from Hercules was submitted by PTC to ERDA as an attachment to the June, 1975, Monthly Technical Letter Report.

In addition to the previous extensive chemical compatibility tests performed by PTC on its explosive, compatibility tests wer e also performed on the water used to manufacture the explosive for each field demonstration. Compatibility tests were also run on well fluids samples obtained prior to the field tests. In all cases, the tests showed that PTC's explosive qualified for use in the field demonstrations. 


\section{HISTORY OF TEST WELLS}

The first two field demonstrations of PTC's chemical explosive fracturing technique were conducted on two wells owned and operated by Hampshire Gas Company. Both wells were completed in the Oriskany sand and were located in Hampshire County near Romney, West Virginia. The first well, Hampshire No. 10, was drilled and completed in 1964. Its initial open flow potential of 10 MCFD was increased to 150 MCFD by treating the zone first with 11,000 gallons of acid and with a subsequent hydraulic fracturing job using 31,500 gallons of water and 28,000 pounds of sand. Isochronal performance tests and casing inspection, temperature, caliper and cement bond logs were run by Hampshire prior to the field test on Well No. 10.

Hampshire Well No. 18, the second test well, was drilled and completed in 1968. Initially the Oriskany sand produced only 5 MCFD. The formation was subsequently treated twice with acid. Altogether, 5000 gallons of $28 \% \mathrm{HCl}, 22,000$ gallons of $15 \% \mathrm{HCl}$ and 10,000 gallons of $5 \% \mathrm{HCl}$ were pumped into the formation. However, there was no measurable increase in gas production as a result of the acid jobs. A pressure buildup test plus casing inspection, caliper and cement bond logs were run on the well prior to the field test:

The third test well was owned and operated by Columbia Gas Corporation. The well, Well No. 20117-T, was drilled and completed in the Devonian shale during late September and early October, 1975. The initial open flow potential of the well was 15 MCFD and a pressure buildup test showed the reservior pressure to be 651 psia and the "conductivity" to be $0.233 \mathrm{md}$. ft. A temperature log indicated no significant gas entry points into the wellbere. 


\section{PREPARATION OF EQUIPMENT \& WELLS}

Preparation of Equipment

Prior to each field demonstration, PTC's equipment was tested extensively and readied for the field tests at $A B L$. Control system tests simulating manufacturing of the explosive using water, were performed before each test. Typical results of these tests showed the percent deviation of the actual versus desired mix ratio of oxidizer to fuel was two (2) percent, well within required explosives manufacturing tolerances.

After tests of the control system, each turbine meter in the system was proved using fresh water. The calculated meter factors comparing actual volumes to metered volumes were to be used to correct metered volumes, calculate tubing capacities and, later on, would be compared to meter factors obtained after the test.

All chemicals for the first two field tests were loaded at $A B L$ and then transported to the well locations. Due to the road weight restrictions and the larger quantity of explosive required for the third test, the oxidizer had to be loaded at the wellsite. The fuel was loaded at ABL and then transported to the wellsite in Virginia. After arriving at the wellsites the oxidizer pump unit, fuel pump unit and data control unit were positioned $60-80$ feet from the wells and all surface lines and control cables strung out. PTC's automatic wellhead assembly was then nomally rigged up and the surface lines and wellhead pressure tested just prior to starting the injectivity tests.

\section{Preparation of Wells}

Prior to each field demonstration a well preparation proceciure was prepared, reviewed and approved by PTC, ERDA and Hampshire or Columbia representatives. These procedures included details for running the downhole equipment, including the 2 "fiberglass tubing string, 1 " stainless steel fuel string, downhole mixer, packer and detonation systems. They also included basic details of the injectivity tests and explosives manufacturing process. The 
procedure for preparing Hampshire No. 18 for the field test is attached as an example. Also cttached is Figure VI-1 which depicts the equipment as it was actually run in this well.

The well preparation procedures were adhered to without significant deviations in all three tests and only minor problems were encountered. The most significant problem was that of retrieving a wireline tubing plug used in the first two tests to pressure test the packer seal cssembly. In both cases difficulty was encountered in equalizing the pressures across the plugs probably due to extraneous matter plugging the equalizing ports. 


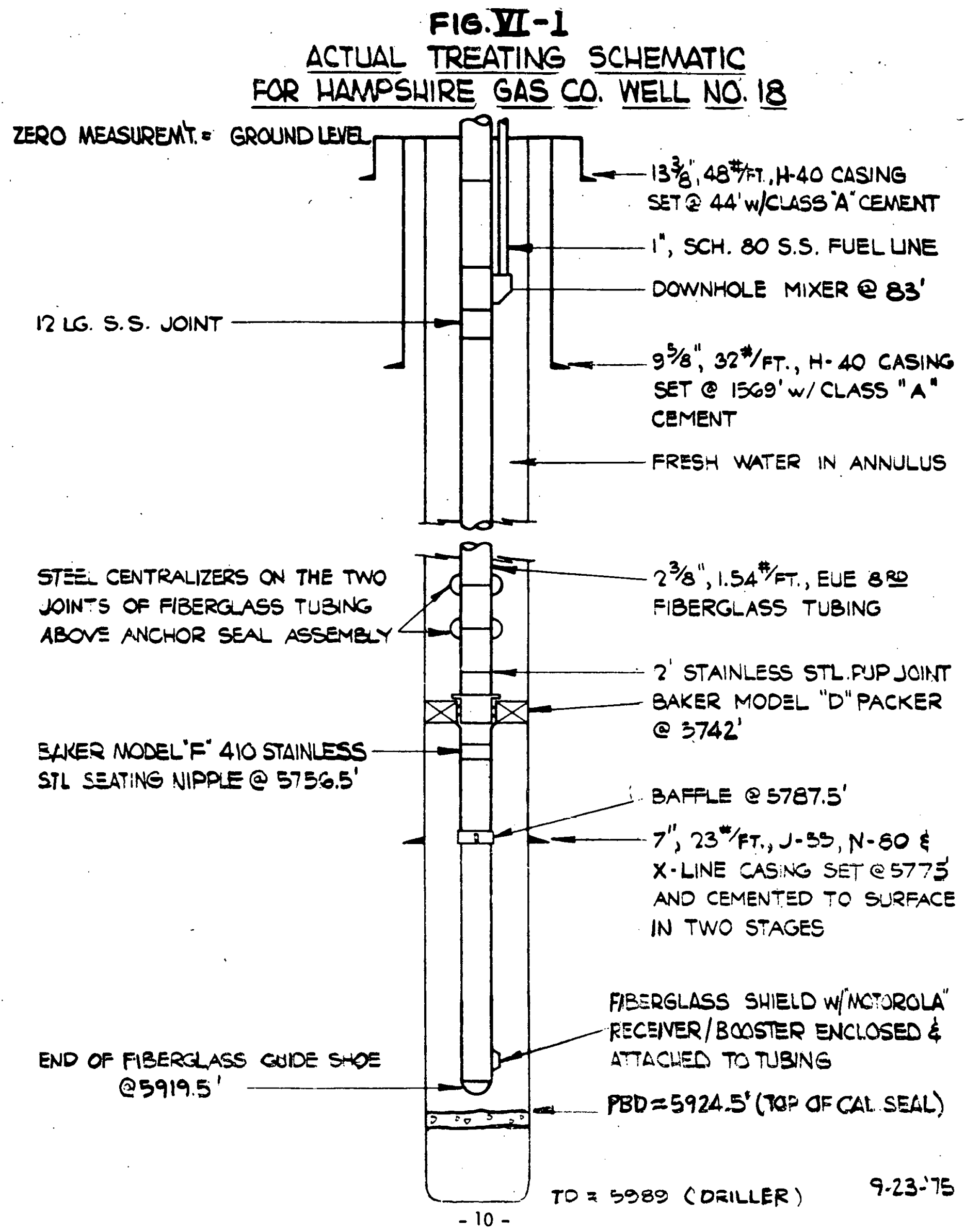




\section{FIELD DEMONSTRATIONS}

Hampshire No. 10

On July 1, 1975, the first field demonstration under this contract was conducted using Hampshire Well No. 10 as the test well. Prior to manufacturing and injecting the explosive, an injectivity test was performed and a backup detonation system, PTC's miniature time bomb, was run in the well on a wireline. During the injectivity test a total of 1752 gallons of fresh water and diesel were injected into the well at an average injection rate of $56.5 \mathrm{gpm}$. Initial injection pressure was 1650 psig but it steadily dropped to zero after pumping approximately one third of the total and remained zero for the duration of the injectivity test.

A total of 1370 gallons of oxidizer and 430.4 gallons of fuel were pumped into the well resulting in 20,171 pounds of PTC -4 explosive being manufactured. The explosive was manufactured at an average rate of $60 \mathrm{gpm}$ against essentially zero pressure. The explosive and Motorola transmitter/wiper plug were then displaced to the baffle with fresh water at an average rate of $45 \mathrm{gpm}$ with a maximum displacement pressure of $600 \mathrm{psig}$. Detonation did not occur after seating the transmitter/wiper plug in the baffle and waiting for the three minute time delay mechanism to "time out". Approximately 1200 psig was then put on the plug and held for $20-30$ minutes to insure that it was in the baffle but detonation still did not occur.

Finally, approximately $5 \frac{1}{2}$ hours after seating the Motorola transmitter/wiper plug, detonation occurred when the time bomb "timed out". Upon detonation the water in the tubing string unloaded and vented to the atmosphere. Detonation gases followed the water and vented for $5-10$ minutes with a steady high pitch roar. The following day the well was produced for a 20 minute period, after which, the shut in tubing pressure increased from 900 to 1800 psig during a 30 minute interval. The well was then shut in to await cleanout operations. 
Hampshire No. 18

Previous treatment data on Hampshire No. 18 indicated that the explosive could be manufactured and injected into the formation without exceeding the 2000 psig working pressure of the fiberglass tubing employed in the PTC process. Initial injectivity tests showed that fresh water could not be injected into the formation without exceeding 2000 psig. Subse quently, the casing-tubing annulus was pressurized to 1000 psig to allow a maximum surface injection pressure of 3000 psig and water was successfully injected into the formation at a maximum rate of $30 \mathrm{gpm}$ and $2800 \mathrm{psig}$ surface pressure. This injection pressure represents a gradient of $0.912 \mathrm{psi} / \mathrm{ft}$, indicating that the Oriskany sand was being hydraulically fractured. The attoched Figure VII-l shows the injection profile for the final water injectivity test.

The explosive was manufactured and injected into the formation at $20-31 \mathrm{gpm}$ at an average surface pressure of 2500 psig which also indicates that the formation was being hydraulically fractured. Sufficient oxidizer and fuel were pumped into the well to manufacture 22,781 pounds of PTC -4 explosive. At least 20,000 pounds of explosive were injected and displaced into the formation matrix or the fracture system. Figure VII-2 is an injection profile showing the average injection pressure and rate while manufacturing the explosive.

The displacement process was hampered by a leaking wellhead assembly valve which allowed hot oxidizer to solidify around the Motorola transmitter/wiper plug. Hot water had to be reverse circulated around the plug to dissolve the oxidizer and free the plug. The hot oxidizer, together with the high pump pressures associated with freeing the Motorola device, . apparently damaged the plug wiper rubbers allowing water to bypass it, since after displacing with the required volume of water, the plug did not seat in the baffle. Therefore, the wellhead assembly valves had to be kept closed to prevent backflow of the explosive into the tubing and above the packer, while waiting for the time bomb to initiate the detonation.

Approximately 2 hours after completing the displacing process the detonation occurred. Since the pressures generated by the detonation were not free to vent to the atmosphere, the hydraulic pressure surge created by the detonotion lifted PTC's well head assembly about 15 to 20 feet into the air and it came to rest about 25 feet from the well with the tubing strings still connected. Very little of the water used to displace the explosive was blown out of the well. A tubing unit was then moved over the well and immediately started the cleanout operations. 

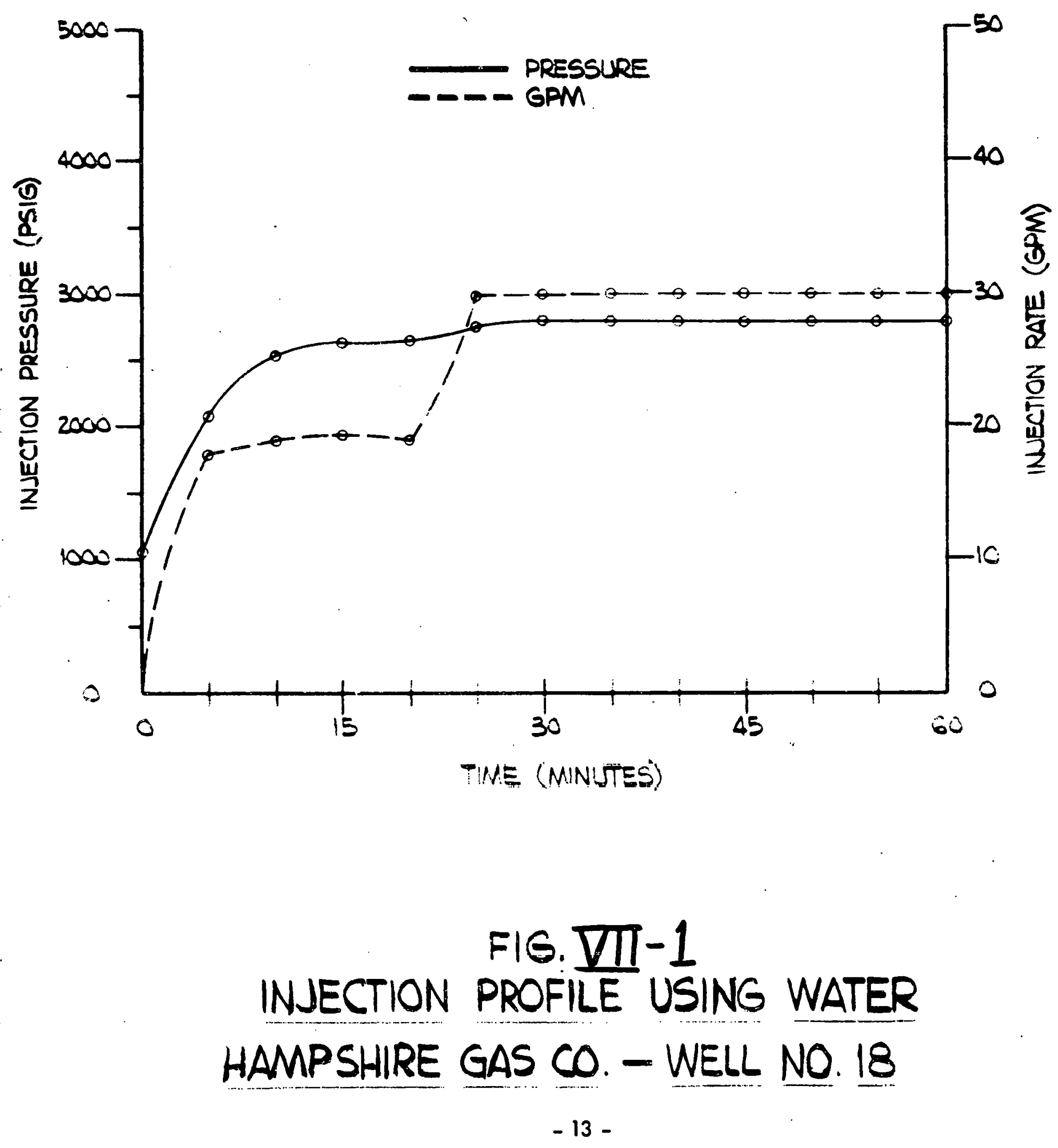


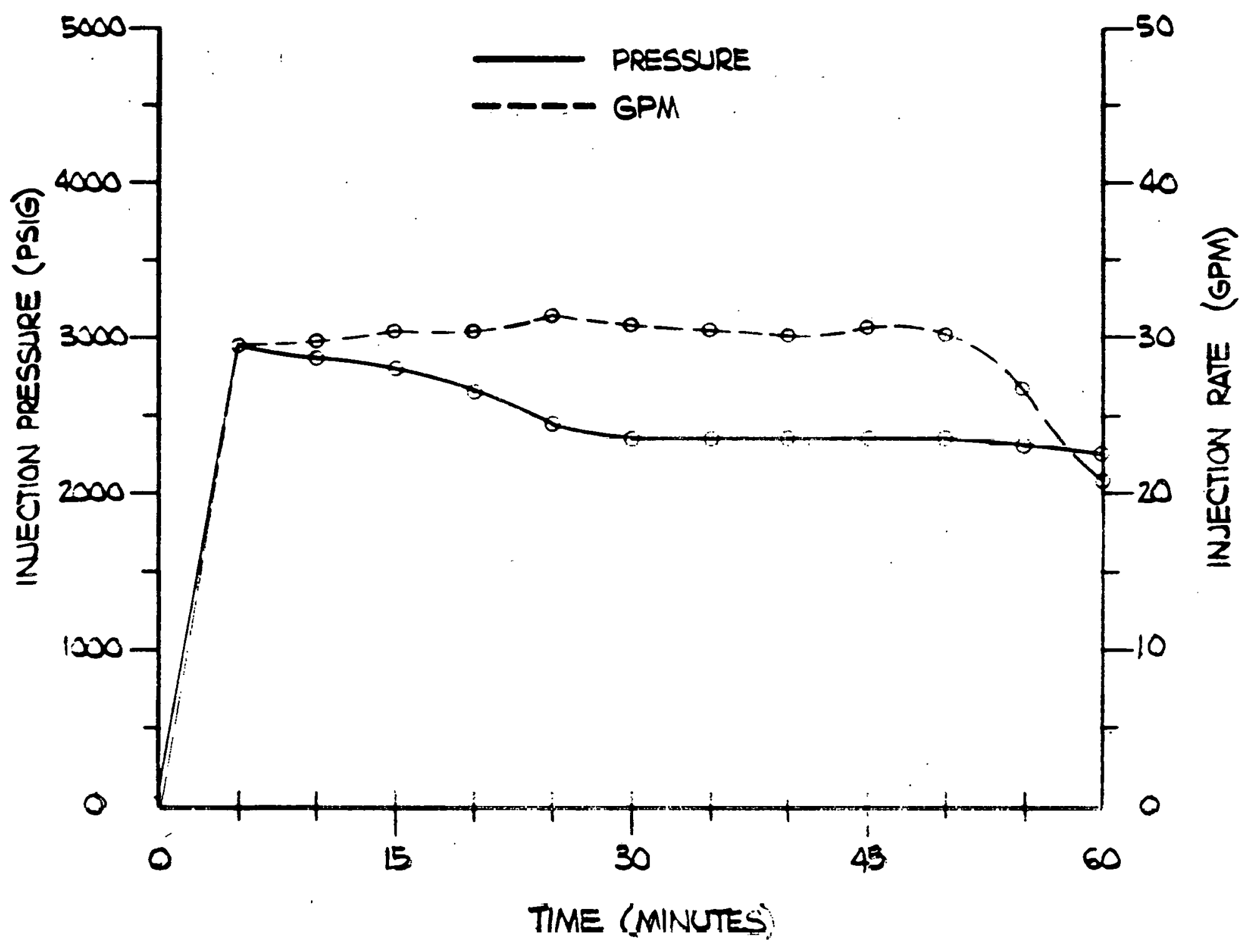

FIG. VIII-2

INJECTION PROFILE DURING EXPLOSIVE MANUFACTURING AND INUECTION HAMPSHIRE GAS CO-WELL NO 18 
Columbia Well No. 20117-T.

Columbia's experience with the Devonian shale formation in the Wise County, Virginia, area indicated that the Devonian shale would easily breakdown with the hydrostatic head of water or the explosive. Therefore, an injectivity test was not performed on Well No. 20117-T prior to running the time bomb and manufacturing the explosive.

On October 24, 1975, 30,323 pounds of PTC -4 explosive were manufactured and injected into the well at an average rate of $39.7 \mathrm{gpm}$ with essentially zero injection pressure. The explosive and Motorola transmitter/wiper plug were then displaced to the baffle with fresh water. When the plug seated in the baffle, the surface pump pressure increased immediately to 1000 psig and preparations were made for the detonation.

The Motorola system again failed to function and approximately one (1) hour later the time bomb detonated the explosive. Mild to medium ground shocks were felt in the immediate area of the well and as far away as two miles. The detonation apparently plugged the tubing since only $1-2$ gallons of water were ejected from the top of the open well lhead assembly. The wellsite was then secured to await initiation of cleanout operations the following day. 


\section{CLEANOUT OF WELLS}

Cleanout of the three test wells was approached in the same basic manner, in that a tubing or service unit was used to retrieve the downhole equipment above the packer or gravel tamp and a rotary rig utilizing air was used to complete the cleanout operations. With the exception of a downhole fire that occurred in Hampshire No. 10, cleanout of the first two wells was straightforward requiring opproximately ten days to rig up and cleanout each well.

Cleanout of Columbia Well No. 20117-T was somewhat more complicated. Difficulty was encountered in retrieving the Baker Model " $D$ " packer because initial attempts to pull it from the well were made before sufficiently milling over the slips to release them. In addition, during the fishing operations a grapple was left in the well and had to be milled up before continuing with the packer removal.

After successfully cleaning out the packer, the open hole section could only be cleaned out to 3299 feet or 630 feet from bottom. At this point the bit and drill pipe became stuck badly and had to be jarred free several times. Upon tripping the pipe it was noted that the drill pipe and bit were covered with "mud", indicating that the hole was wet. Air was subsequently circulated for ten hours to dry the hole but another attempt to cleanout further resulted in becoming stuck again. Cleanout operations were then suspended. It is thought that the water causing the cleanout difficulties resulted from a poor cement job caused by attempting to cement the 7" casing with the shoe 270 feet off bottom. Apparently the water leak which was evidenced by development of a "mud ring" while drilling out be low the casing, was intensified by the shot and created conditions impossible to clean out with the available equipment. 


\section{EVALUATION OF RESULTS}

Hampshire No. 10

Comparison of caliper surveys run before and after the detonation indicates that the diameter of the open hole section from the casing shoe to 5230 feet had increased from 6 inches to $7-7 \frac{1}{2}$ inches. The interval below 5230 feet had increased in diameter to $9-10$ inches.

Isochronal backpressure tests were run on Hampshire No. 10 before and after the test. Shut in tubing pressure before the original backpressure tests was 1983 psia as compared to 1980.1 psia after the detonation. Comparison of the results of the two series of backpressure tests indicates that there was no change in gas deliverability as a result of the chemical explosive fracturing test.

Hampshire No. 18

The caliper surveys run after the test showed that an elliptical hole had been created from $5772-5840$ feet. No gas deliverability tests had been performed on this well before the test but pressure buildup data obtained before and after the test was used to determine the changes, if any, in the well's producing characteristics. The results of these pressure buildup tests, which are summarized below, show that even though the gas productivity of the well was not increased to commercial quantities, the inflow characteristics were improved by a factor of 1.66 .

\begin{tabular}{|c|c|c|c|}
\hline \multirow[b]{2}{*}{ Day } & \multicolumn{2}{|c|}{ Before Explosive Stimulation } & \multirow[b]{2}{*}{$\begin{array}{c}\text { Rate } \\
\text { (SCF/Day) }\end{array}$} \\
\hline & $\begin{array}{l}\text { Pressure } \\
\text { (psia) } \\
\end{array}$ & $\begin{array}{l}\text { Volume } \\
(S \subseteq F)\end{array}$ & \\
\hline 2 & 110 & 9,668 & \\
\hline 4 & 205 & 18,241 & 4,286 \\
\hline
\end{tabular}




\section{After Explosive Stimulation}

\begin{tabular}{|c|c|c|c|}
\hline Day & $\begin{array}{l}\text { Pressure } \\
\text { (psia) }\end{array}$ & $\begin{array}{l}\text { Volume } \\
\text { (SCF) }\end{array}$ & $\begin{array}{c}\text { Rate } \\
\text { (SCF/Day) } \\
\end{array}$ \\
\hline 2 & 149 & 13,150 & \\
\hline 4 & 304 & 27,387 & 7,118 \\
\hline
\end{tabular}

Columbia No. 20117-T

Due to the limited cleanout of the open hole section in this well a caliper survey was not run after the detonation. Production tests and pressure buildup surveys were run before and after the detonation. The results of these tests, which are summarized below, indicate that a significant productivity increase was achieved by the explosive stimulation test but a commercial well was not obtained.

\begin{tabular}{|c|c|c|}
\hline & Before Shot & After Shot \\
\hline Reservoir Pressure & 651 & 459 \\
\hline Kh (conductivity) & $0.233 \mathrm{md}-\mathrm{ft}$ & $2.148 \mathrm{md}-\mathrm{ft}$ \\
\hline Skin Effect Range & $\begin{array}{lll}-1.343 & \mathrm{~S} & -3.758\end{array}$ & $\begin{array}{lll}-2.812 & S & -5.225\end{array}$ \\
\hline Initial Open Flow & 15 MSCFPD & 43 MSCFPD \\
\hline Stabilization Time & 189 Hours & 956 Hours \\
\hline Open Hole Section Surveyed & $780^{\prime}$ & $150^{\prime}$ \\
\hline
\end{tabular}


ERDA NOTE:

\section{COST OF THE 3-WELL TEST PROGRAM}

Total estimated cost of PTC service (original contract) $=\$ 317,995$

Approx. actual cost of PTC service (including

Columbia Gas Co. field test support)

$=\$ 456,100$

Cost of well preparation, cleanout and testing of 2 Hampshire Gas wells

$$
=\frac{\$ 224,400}{\$ 680,500}
$$

